This is a postprint (final submitted manuscript) version of the following article:

Parris, D., \& Welty Peachey, J. (2013). A systematic literature review of servant leadership theory in organizational contexts. Journal of Business Ethics, 113(3), 377-393. https://doi.org/10.1007/s10551-012-1322-6 


\section{Journal of Business Ethics \\ A Systematic Literature Review of Servant Leadership Theory in Organizational Contexts \\ --Manuscript Draft--}

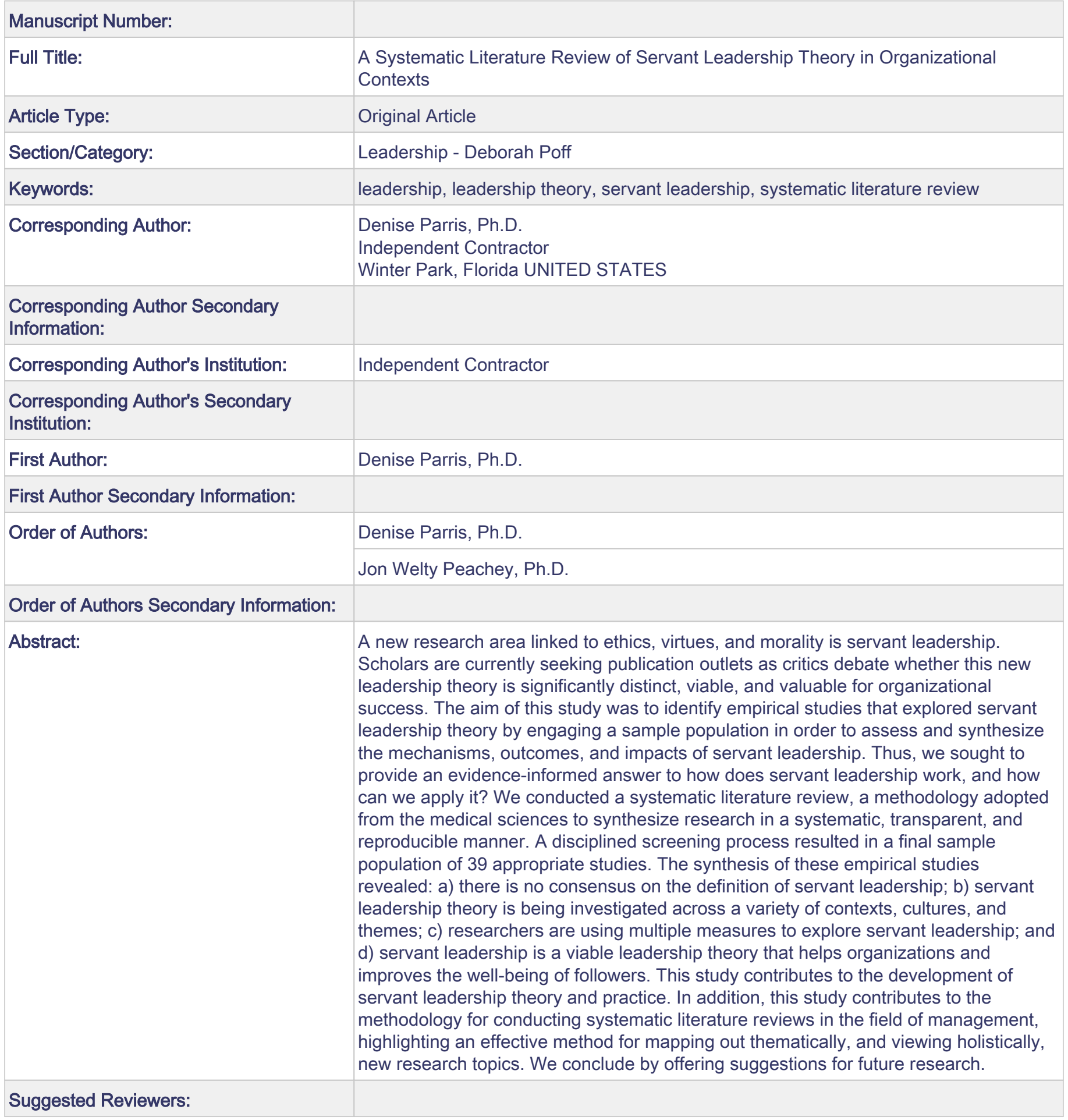


A Systematic Literature Review of Servant Leadership Theory in Organizational Contexts

\author{
Dr. Denise Linda Parris* \\ 1044 N Kentucky Ave \\ Winter Park, FL 32789 \\ 352-217-6630 \\ deniselparris@gmail.com \\ Dr. Jon Welty Peachey \\ Assistant Professor \\ Division of Sport Management \\ Department of Health and Kinesiology \\ 4243 TAMU \\ Texas A\&M University \\ College Station, TX 77843 \\ 979-845-2191 \\ jweltypeachey@hlkn.tamu.edu \\ *Corresponding author
}




\title{
A Systematic Literature Review of Servant Leadership Theory in Organizational
}

\section{Contexts}

\begin{abstract}
A new research area linked to ethics, virtues, and morality is servant leadership. Scholars are currently seeking publication outlets as critics debate whether this new leadership theory is significantly distinct, viable, and valuable for organizational success. The aim of this study was to identify empirical studies that explored servant leadership theory by engaging a sample population in order to assess and synthesize the mechanisms, outcomes, and impacts of servant leadership. Thus, we sought to provide an evidence-informed answer to how does servant leadership work, and how can we apply it? We conducted a systematic literature review, a methodology adopted from the medical sciences to synthesize research in a systematic, transparent, and reproducible manner. A disciplined screening process resulted in a final sample population of 39 appropriate studies. The synthesis of these empirical studies revealed: a) there is no consensus on the definition of servant leadership; b) servant leadership theory is being investigated across a variety of contexts, cultures, and themes; c) researchers are using multiple measures to explore servant leadership; and d) servant leadership is a viable leadership theory that helps organizations and improves the well-being of followers. This study contributes to the development of servant leadership theory and practice. In addition, this study contributes to the methodology for conducting systematic literature reviews in the field of management, highlighting an effective method for mapping out thematically, and viewing holistically, new research topics. We conclude by offering suggestions for future research.
\end{abstract}

Keywords: leadership, leadership theory, servant leadership, systematic literature review 


\section{INTRODUCTION}

Leadership is one of the most comprehensively researched social influence processes in the behavioral sciences. This is because the success of all economic, political, and organizational systems depends on the effective and efficient guidance of the leaders of these systems (Barrow, 1977). A critical factor to understanding the success of an organization, then, is to study its leaders. Leadership is a skill used to influence followers in an organization to work enthusiastically towards goals specifically identified for the common good (Barrow, 1977; Cyert, 2006; Plsek and Wilson, 2001). Great leaders create a vision for an organization, articulate the vision to the followers, build a shared vision, craft a path to achieve the vision, and guide their organizations into new directions (Banutu-Gomez and Banutu-Gomez, 2007; Kotter, 2001). According to Schneider (1987), the most important part in building an organization with a legacy of success is the people in it, which includes the followers (i.e., employees and volunteers) as well as the leaders. Leadership theories attempt to explain and organize the complexity of the nature of leadership and its consequences (Bacharach, 1989; Bass and Bass, 2008). Over the years, some leadership scholars have called attention to the implicit connection between ethics and leadership. A burgeoning new research area and leadership theory that has been linked to ethics, virtues, and morality is servant leadership (Graham, 1991; Lanctot and Irving, 2010; Parolini et al., 2009; Russell, 2001; Whetstone, 2002).

Servant leadership theory's emphasis on service to others and recognition that the role of organizations is to create people who can build a better tomorrow resonates with scholars and practitioners who are responding to the growing perceptions that corporate leaders have become selfish and who are seeking a viable leadership theory to help resolve the challenges of the $21 \mathrm{st}$ century. Despite servant leadership being coined by Robert K. Greenleaf over three decades ago 
in 1970, it remains understudied yet still prominently practiced in boardrooms and organizations (Bass and Bass, 2008; Spears, 2005). It has received significant attention in the popular press (e.g., Fortune magazine and Dateline) (Spears Center, 2011) and leading organizational management authors have discussed the positive effects of servant leadership on organizational profits and employee satisfaction; see Max DePree (Leadership is an Art, 1989), Stephen Covey (Principle Centered Leadership, 1990), Peter Senge (The Fifth Discipline: The Art and Styles of the Learning Organization, 1990), Peter Block (Stewardship: Choosing Service over Self Interest, 1993), and Margaret Wheatley (Finding Our Way: Leadership in an Uncertain Time, 2005). However, Greenleaf's $(1970,1977)$ conceptualization of servant leadership as a way of life rather than as a management technique perhaps has slowed the acceptance of this leadership theory in academia as scholars ask the question: If it is a way life - a philosophy, how can it be empirically tested? Even Greenleaf admitted servant leadership is unorthodox and would be difficult to operationalize and apply, as "it is meant to be neither a scholarly treatise nor a howto-do-it manual" (Greenleaf, 1977, p. 49). The majority of research to date on servant leadership consists of developing theoretical frameworks and establishing measurement tools with the intention that future scholars can apply these tools to explore servant leadership in practice and as a tenable theory. Only a limited amount of research has empirically examined this construct.

As an aid in advancing servant leadership theory, we sought to identify these empirical studies that investigated servant leadership by engaging a sample population in order to assess and synthesize its mechanisms, outcomes, and impacts. Currently, there does not exist a comprehensive summary of empirical studies exploring servant leadership theory in organizational settings (e.g., a systematic literature review), which is a gap in the extant 
literature. Through exploring empirical studies investigating servant leadership theory in organizational contexts, we provide evidence that servant leadership is a tenable theory.

As a promising new field of research, servant leadership faces the challenges once addressed by the early services marketing and sport management scholars whose new ideas and concepts were accepted slowly within the conservative culture of academia (Shannon, 1999). Similarly, servant leadership scholars have sought a variety of publication outlets for their work while they confront a debate on the distinctiveness and significance of this leadership theory for organizations as well as employees. In addition, the acceleration of knowledge production in the management field has resulted in a body of knowledge that is increasingly transdisciplinary, fragmented, and interdependent from advancement in social sciences. In management research the literature review is a key tool used to manage the diversity of knowledge for an academic inquiry; however, a critique of these reviews is that they are typically descriptive accounts of contributions of selected writers often arbitrarily chosen for inclusion by the researcher, and that these reviews may lack a critical assessment of included studies (Tranfield et al., 2003). In contrast, a systematic literature review (SLR) is different from traditional narrative reviews in that it adopts a replicable, scientific and transparent process that aims to mitigate bias through exhaustive literature searches and by providing an audit trail of the conclusions. A current gap in management research is a discussion of how to conduct a SLR, how to critically assess studies, and how to integrate the conclusions. In this SLR, we not only ascertain the current state of the field in servant leadership research and synthesize divergent studies, but also advance a rigorous methodology for conducting a SRL in management research.

Thus, the purpose of this study was to systematically examine and organize the current body of research literature that either quantitatively or qualitatively explored servant leadership 
theory in a given organizational setting. In this SRL we only included empirical studies that investigated servant leadership in an organizational context and excluded studies with a primary focus on model development or testing measurement instruments. Earlier reviews on the concept of servant leadership focused on: identifying key characteristics (Russell and Stone, 2002), measurement development (Barbuto and Wheeler, 2006), and proposing a theoretical framework (Van Dierendonck, 2011). Although these reviews help provide insight into how researchers have attempted to operationalize servant leadership, none of them was done in a systematic manner (i.e., no methodology to select articles or limit bias), and none of them specifically explored empirical research.

The following research questions guided this SLR: a) how was servant leadership defined?; b) in what contexts was servant leadership theory empirically investigated?; c) how was servant leadership examined (i.e., the methodology)?; and, d) what were the results of the examination? We begin this paper by summarizing the origin of servant leadership and follow with a short discussion of the development of servant leadership as a theory and a new research area. Next, a summary of the method used for selecting and reviewing the literature is explained, with details on search strategy, analysis, and assessment of the quality of the reviewed studies. Then, we present our findings of the SLR on empirical studies that have explored servant leadership theory. In addition, we discuss the methodological contribution of conducting SLRs in the field of management as an effective method for mapping out thematically, and viewing holistically, new research topics. We conclude by offering suggestions for future research and practice. 


\section{ORIGIN OF SERVANT LEDERSHIP BY ROBERT K. GREENLEAF}

Servant leadership was introduced into an organizational context through Greenleaf's three foundational essays - The Servant as Leader (1970), The Institution as Servant (1972), and Trustees as Servants (1972) - all of which he published after retiring from 40 years of management work at AT\&T. Greenleaf (1977) defined servant leadership as not just a management technique but a way of life which begins with "the natural feeling that one wants to serve, to serve first" (p. 7). Greenleaf (1977) conceptualized the servant as leader from his impressions of Journey to the East by Hesse (1956) and used the character Leo to describe a true servant: "Leadership was bestowed upon a man who was by nature a servant. . . . His servant nature was the real man, not bestowed, not assumed, and not to be taken away" (p. 21). Servant leaders are distinguished by both their primary motivation to serve (what they do) and their selfconstruction (who they are), and from this conscious choice of 'doing' and 'being' they aspire to lead (Sendjaya and Sarros, 2002). Greenleaf (1977) believed servant leadership was an inward lifelong journey.

Upon retirement in 1964, Greenleaf launched a second career, which spanned 25 years, in which he articulated his new leadership paradigm - servant leadership. He promoted servant leadership in many publications and presentations, including lectures at Massachusetts Institute of Technology’s (M.I.T.) Sloan School of Management, Harvard Business School, Dartmouth College, and the University of Virginia; and served as leadership consultant to institutions such as Ford Foundation, Lilly Endowment, M.I.T., R.K. Mellon Foundation, and the American Foundation for Management. In 1964 he founded the Center for Applied Ethics, renamed the Robert K. Greenleaf Center for Servant Leadership in 1985, which helps people understand the principles and practices of servant leadership (Greenleaf Center, 2011). Over 20\% of Fortune 
magazine top 100 companies have sought guidance from the Greenleaf Center for Servant Leadership, such as Starbucks, Vanguard Investment Group, Southwest Airlines, and ID Industries (Greenleaf Center).

Although the contemporary study of servant leadership evolved largely from Greenleaf $(1970,1977)$, the practice of servant leadership is not a new concept, with roots dating back to ancient teachings of the world's great religions, as well as to statements of numerous great leaders and thinkers (Sendjaya and Sarros, 2002). The concept of servant leadership echoes the messages of Mother Theresa, Moses, Harriet Tubman, Lao-tzu, Mohandas Gandhi, Martin Luther King, Jr., Confucius, and many other religious, historic, and current leaders (Keith, 2008). Many scholars model Jesus Christ's teachings to his disciples as the ultimate example of servant leadership (Ebener and O’Connell; Lanctot and Irving, 2010; Winsten, 2004). Whereas other leadership theories are traditionally defined only by what the leader does, servant leaders are defined by their character and by demonstrating their complete commitment to serve others. This creates one of the core challenges for theorists; how to construct models that encompass Greenleaf's theoretical message of "servanthood-through-leadership-through-practice" (Prosser, 2010 , p. 28) that operates not only on a surface-level but deep within a person's being. Although scholars have agreed theories, frameworks, and models will increase our understanding of the meaning, implications, and applications of servant leadership, it is important to remain aware of the more abstract, underlying principles and concepts of a servant as a leader (Spears, 1998; Keith, 2008; Prosser, 2010).

\section{SERVANT LEADERSHIP AS A THEORY}

Although servant leadership is a growing trend being practiced by private and non-profit organizations alike, there is still a lack of research in this area (Farling et al., 1999). The majority 
of research in servant leadership has streamed from Greenleaf's (1977) foundational texts and the Greenleaf Center (see Akuchie, 1993; Bordas, 1995; Brody, 1995; Buchen, 1998;

Chamberlain, 1995; Frick, 1995; Gaston, 1987; Kelley, 1995; Kiechel, 1995; Kuhnert and Lewis, 1987; Lee and Zembke, 1995; Llyod, 1996; Lopez, 1995; McCollum, 1995; McGee-Cooper and Trammell, 1995; Rasmussen, 1995; Rieser, 1995; Senge, 1995; Smith, 1995; Snodgrass, 1993; Spears, 1995, 1996; Tatum, 1995; Vanourek, 1995). Many of these writers present narrative examples of how servant leadership is being used in organizational settings; however, this is also the primary limitation of much of the servant leadership literature, which is anecdotal in nature instead of empirical (Bowman, 1997; Northouse, 1997; Sendjaya and Sarros, 2002). Bass (2000) acknowledged that servant leadership requires extensive research, emphasizing that "the strength of the servant leadership movement and its many links to encouraging follower learning, growth, and autonomy, suggests that the untested theory will play a role in the future leadership of the learning organization" (p. 33). The promise of servant leadership has since motivated scholars and practitioners to explore the possibilities of the servant-first paradigm.

Since Farling et al.'s (1999) call for empirical studies, there have emerged three streams of research (Van Dierendonck and Patterson, 2011): a) a conceptual stream (Spears, 1998; Laub, 1999; Patterson, 2003); b) a measurement stream (Page and Wong, 2000; Wong and Page, 2003; Ehrhart, 2004; Barbuto and Wheeler, 2006; Dennis and Bocarnea, 2005; Liden et al., 2008; Sendjaya et al., 2008; Van Dierendonck and Nuijte, 2011); and c) model development (Russell and Stone, 2002; Van Dierendonck, 2011). Notably absent from the above streams are empirical studies that explore servant leadership theory in a given organizational setting. In addition, in spite of the growing amount of research on servant leadership, the theory is still under-defined, with various authors grappling with definitions (Anderson, 2009). This is as Greenleaf (1977) 
predicted, when he warned that servant leadership would be difficult to apply and operationalize. He did not provide a management how-to-do-it-manual; instead, he challenged readers to reflect, ponder, and grow (Frick, 2004; Spears, 1995).

To date, three reviews of servant leadership have been conducted, which help provide insight into how researchers have organized the complexity of Greenleaf's concepts on servant leadership into a theoretical framework. Russell and Stone's (2002) review revealed the following nine functional attributes, or operative qualities and distinctive characteristics of servant leaders; vision, honesty, integrity, trust, service, modeling, pioneering, appreciation of others, and empowerment. In addition, Russell and Stone determined 11 accompanying attributes, which are interrelated and supportive of the nine core attributes listed above: communication, credibility, competence, stewardship, visibility, influence, persuasion, listening, encouragement, teaching and delegation. From this assimilation of attributes Russell and Stone developed a model of servant leadership to spark future application and research. While their review provides a conceptual overview of servant leadership, it lacks a methodology. Barbuto and Wheeler (2006) developed an integrated model of servant leadership after conducting a literature review, which synthesized the attributes of servant leadership into five factors; altruistic calling, emotional healing, persuasive mapping, wisdom, and organizational stewardship. The third review by Van Dierendonck (2011) also concludes with another conceptual model, which identifies six key characteristics of servant leadership: empowering and developing people, humility, authenticity, interpersonal acceptance, providing direction, and stewardship. All of these reviews exemplify different interpretations of Greenleaf's writings employing different terminologies; however, all include the fundamental dimension of servanthood or the willingness to serve others. These reviews highlight the plurality of servant 
leadership theory, leaving the researcher, student, or practitioner to ponder exactly what servant leadership theory is. As DiMaggio (1995) pointed out "there is more than one kind of good theory" (p.391).

Given that previous reviews have examined the development of conceptual frameworks and measurement tools for servant leadership, the present review focuses only on empirical studies that have explored servant leadership theory in an organizational context. As such, the current study is the first review to provide a synthesis, based upon evidence in published peer reviewed journals, of empirical studies conducted on servant leadership theory in organizational settings.

\section{METHODOLOGY}

The SLR is often contrasted with traditional literature reviews because systematic reviews are objective, replicable, systematic, comprehensive, and the process is reported in the same manner as for reporting empirical research (Weed, 2005). The origin of SLRs is in the medical, health care, and policy fields, where they have been used to assemble the best evidence to make clinical and policy decisions (Cook et al., 1997; Tranfield et al., 2003). SLRs in management are used to provide transparency, clarity, accessibility, and impartial inclusive coverage on a particular area (Thorpe et al., 2006). Klassen et al (1998) define SLR as "a review in which there is a comprehensive search for relevant studies on a specific topic, and those identified are then appraised and synthesized according to a pre-determined explicit method" (p. 700). This SRL specifically explored research studies that have examined servant leadership theory in a given organizational setting. Since our focus was gaining insight on the empirical investigation of servant leadership theory, we excluded studies with a primary focus on model development or testing measurement instruments. The approach of this review entailed extensive 
searches of relevant databases with the intention of ensuring, as far as possible, that all literature on servant leadership was identified while maintaining the focus on literature of greatest pertinence to the research questions - (i.e., empirical studies that have investigated servant leadership theory in organizational settings). Next, we discuss our search methods, inclusion and exclusion criteria, sample, and data analysis.

\section{Search Methods}

Published studies were identified through searches of electronic databases accessible through the authors' university library system. Databases included in this review were: PsycInfo, Eric, Sociological Abstracts, PAIS International, Social Services, Communication Abstracts, International Bibliography of the Social Sciences (IBSS), Physical Education Index, World Wide Political Abstracts from the vendor CSA, Academic Search Complete, Business Source Complete, Communication and Mass Media Complete, Education and Administration Abstracts, Gender Studies, CINAHL, Health Source: Nursing/Academic Edition, Human Resources Abstracts, and Medline through the vendor EBSCO. All results were limited to English-only peer reviewed journal articles. The searches for published studies were conducted in a systematic manner, following the order of the databases listed above.

\section{Inclusion and Exclusion Criteria}

The initial search required that articles included in the review were studies that must: a) be published in a peer-reviewed journal; b) be in the English language; and (c) use the keyword “servant leadership.” No restriction was placed on year of publication. The number of articles containing the keyword "servant leadership" retrieved from each database was recorded. Next, we examined if there were any external duplicates from the current database being searched and the previous databases that had already been searched. We recorded the number of external 
duplicates, and then deleted the duplicated journal articles from the last database searched while keeping a running total of new articles found.

Once all possible studies had been identified, we conducted a second screening to assess eligibility against inclusion criteria and then full text articles were retrieved for those that met the inclusion criteria. The inclusion criteria for the second screening required that the published peer-reviewed article meet all of the following four specifications: a) be in the English language; b) be an empirical study (i.e., not an essay, book review, letter, literature review, editorial, opinion, journalistic or antidotal article); c) discuss servant leadership as the main topical theme; and d) examine servant leadership theory either quantitatively or qualitatively. Articles were excluded if any of these four components was not addressed in the abstract, results, or discussion sections of the respective study. Finally, additional articles meeting the inclusion criteria were found by examining the bibliographies of resources identified through the secondary screening.

\section{Sample}

Peer reviewed publications were identified using the key terms outlined in the inclusion and exclusion criteria section above. In all, a total of 381 articles where retrieved; however, after duplicates were deleted there remained 255 articles meeting the initial inclusion criteria. After the secondary search process was conducted, a final sample of 44 appropriate studies was obtained. Upon retrieving full text articles, an additional five articles were excluded after further examination because they did not satisfy the screening criteria. The final sample of articles constituted 39 empirical studies. Peer-reviewed articles meeting the outlined criteria were published between 2004 and 2011. The 39 published articles were drawn from a variety of peerreviewed journals $(n=27)$. Table 1 depicts the list of journals included in the study, the number of articles included from each journal, and the database they were accessed through. 
Insert Table 1 about here

We grouped the journals by their area of focus, which showed a concentration of research taking place in leadership $(n=9)$, education $(n=7)$, business $(n=6)$, and psychology $(n=6)$, with the fields of nursing $(n=3)$, management $(n=2)$, personal selling and sales management $(n=2)$, ethics $(n=1)$, parks and recreation administration $(n=1)$, services marketing $(n=1)$, and sports $(n=1)$ representing a smaller number of empirical studies.

\section{Data Analysis}

The Matrix Method (Garrard, 1999) was utilized as the strategy for organizing and abstracting pertinent information from these publications. For this study, the following information was abstracted from each article: a) how was servant leadership defined? b) in what contexts was servant leadership theory empirically investigated? c) how was servant leadership examined? and d) what were the results of the examination? Last, for each publication, the methodology used to examine servant leadership was evaluated. For qualitative studies, we used a critical appraisal tool designed by Letts et al. (2007), and for quantitative studies we used a critical appraisal tool designed by the Institute for Public Health Sciences (2002). In addition to these two appraisal assessments we used Stoltz, Udén, and William's (2004) critical appraisal tool, which assessed both quantitative and qualitative studies. We adopted these three critical appraisal tools to create a three-point scale to reflect the quality of studies: high (I); medium (II) - used if studies did not meet criteria for high (I) or low quality; and low (III). Table 2 describes our classification for high to low quality studies, which was based on the three critical appraisal tools mentioned above. 
Insert Table 2 about here

The findings from these studies were summarized and placed into matrixes (i.e., tables). Our SLR findings consist of a synthesis of the results from all 39 empirical studies along with the assessment of quality for each study. Further, we assess the level of supporting evidence for thematic conclusions drawn from combining the results of multiple studies.

\section{FINDINGS}

Overall, this review highlights that servant leadership theory is being researched and tested across a variety of contexts, cultures, disciplines, and themes. Our sample included 11 qualitative studies, 27 quantitative studies, and one mixed method study, all empirically assessing servant leadership theory. Thus, this review illustrates that servant leadership is being explored both quantitatively and qualitatively, and the topic has an international appeal with studies being conducted in 11 countries. In the quality assessment, 22 studies were classified as high, 12 as medium, and five as low quality. Conclusive statements were made based upon the synthesis of findings from each article. The conclusions (see Table 3) were classified as A (strong evidence) or B (moderate evidence) based on scientific strength.

\section{Insert Table 3 about here}

If two or more studies of high quality supported a conclusion or one study of high quality in addition to two or more studies of medium quality supported the conclusion, we assigned it an (A) rating. On the other hand, conclusions with one study of high quality and one study of 
medium quality or two studies of medium quality were assigned a (B) rating. If a conclusion(s) did not fall under (A) strong evidence in favor of conclusion or (B) moderate evidence in favor of conclusion, we classified it as insufficiently supported and labeled insufficient evidence. The following discussion of our findings is organized around the four central research questions.

\section{How was Servant Leadership Defined?}

Servant leadership theory was introduced to readers by authors of empirical studies by citing one or all three of the following: Greenleaf (1977), Spears (1995, 1998, 2004), and Laub (1999). Generally, authors described servant leadership by quoting one of these three authors in addition to citing multiple other authors, including, but not limited to: Barbuto and Wheeler (2006), Graham (1991), Ehrhart (2004), Liden et al., (2008), Page and Wong (2000), and Patterson (2003). Here, we discuss the three most cited authors on servant leadership that have provided definitions.

Greenleaf $(1970,1972,1977)$, the grandfather of servant leadership, was cited by 37 of the 39 empirical studies. The majority of authors used part or all of Greenleaf's description from his original essay, The Servant as Leader (1970):

It begins with the natural feeling one wants to serve, to serve first. Then conscious choice brings one to aspire to lead. That person is sharply different from one who is leader first. ... The difference manifests itself in the care taken by the servant-first to make sure that other people's highest priority needs are being served. The best test, and difficult to administer, is this: Do those served grow as persons? Do they, while being served, become healthier, wiser, freer, more autonomous, more likely themselves to become servants? And, what is the effect on the least privileged in society? Will they benefit or at least not be further deprived? (Greenleaf, 1970 as cited in Greenleaf 1977, p. 27). 
The majority of authors in our sample, like Greenleaf himself, defined servant leadership theory in a descriptive manner. These descriptions usually cited multiple scholarly works in the conceptual and measurement research streams, in addition to citing leading organizational management authors.

The second most referenced author defining servant leadership theory was Larry Spears. Like Greenleaf, Spears gained his knowledge from practice with most of his works being nonempirical. He served for 17 years as the head of the Greenleaf Center, has authored more than 10 books on servant leadership, and in 2008 established the Larry C. Spears Center for Servant Leadership, Inc. (Spears Center, 2011). Spears (1995, 1998, 2004) identified 10 characteristics of servant leaders from Greenleaf's writings: listening, empathy, healing, awareness, persuasion, philosophy, conceptualization, foresight, stewardship, commitment to the growth of people, and building community. These attributes are described in Table 4.

Insert Table 4 about here

Four of the qualitative studies in our sample used Spear's 10 characteristics to inform their analysis (Crippen, 2004; Crippen and Wallin, 2008a, 2008b; Strum, 2009).

The third most cited author in defining servant leadership theory is Laub (1999). His Organizational Leadership Assessment (OLA) was an outcome of his dissertation. The OLA assesses an organization's health based upon the six key areas of an effective servant-minded organization by exploring the perceptions of top leaders, managers and supervisors, and the workforce; however, it does not assess the servant leadership of individual leaders (OLA Group, 2011). Authors in our sample used Laub's definition, which terms the practice of servant 
leadership as placing "the good of those led over the self-interest of the leader" (1999, p. 81). In addition, authors would list and describe Laub's six key variables of an effective servant-led organization: a) values people - believing, serving, and non-judgmentally listening to others; b) develops people - providing learning, growth, encouragement and affirmation; c) builds community - developing strong collaborative and personal relationships; d) displays authenticity - being open, accountable, and willing to learn from others; e) provides leadership - foreseeing the future, taking initiative, and establishing goals; and f) shares leadership - facilitating and sharing power. The OLA has been widely used in health organizations (OLA Group), and was used in six quantitative studies in our sample (Herman, 2010; Black, 2010; Cerit, 2010; Cerit, 2009; Irving and Longbotham, 2007; Joseph and Winston, 2005).

In summary, our results confirm Anderson's (2009) and Van Dierendonck's (2011) assessments that servant leadership theory remains under-defined with no consensus on its definition or theoretical framework. Scholars are still seeking to articulate Greenleaf's conceptualization of servant leadership by using a variety of definitions sourced from multiple works.

\section{In what Contexts was Servant Leadership Theory Empirically Investigated?}

Our sample illustrates servant leadership theory is being studied across cultures, contexts, and across a diversity of research foci. Overall, the sample consisted of studies in 11 countries, which included four cross-cultures studies. These findings demonstrate that servant leadership is being practiced in various cultures, specifically: U.S. $(n=23)$, Canada $(n=4)$, China $(n=2)$, Turkey $(n=2)$, Indonesia $(n=1)$, New Zealand $(n=1)$, Kenya $(n=1)$, and the Republic of Trinidad $(\mathrm{n}=1)$, with five cross-culture studies comparing U.S. and Ghana, U.S. and UK, U.S. and China $(\mathrm{n}=2)$, and Indonesia and Australia. 
A contextual analysis of the sample revealed that servant leadership theory is being applied in the following organizational settings: education $(n=17)$, which consisted of religious schools $(n=6)$ and secular schools $(n=11)$; secular for profit organizations $(n=17)$, which notably included financial services $(n=4)$ and nursing $(n=3)$; public organizations $(n=2)$; religious organizations $(n=1)$; non-profit organizations $(n=1)$; and in a historical context $(n=1)$. It is important to note that servant leadership was examined in a religious context in seven of the 39 studies, and that the education field represents $44 \%$ of the contextual environment for the entire sample.

This synthesis also revealed seven key research themes, with some studies containing more than one area of focus. The themes and their associated studies are presented in Table 3 . An overall count and description of each theme is as follows: a) cross-cultural applicability acceptance, practices, and different weights of servant leadership in a variety of cultures $(n=7)$; b) servant leadership attributes - conceptual models characteristics were studied $(n=7)$; c) team level effectiveness - effects of servant leadership explored at the unit level $(n=20)$; d) followers' well-being - effects on employees in a servant-led environment $(n=20)$; e) spirituality connection between spiritual workplace and servant-led workplace was investigated $(n=1) ; f)$ demographics $(\mathrm{n}=3)$; and $\mathrm{g})$ implementation of servant leadership $(\mathrm{n}=3)$. We discuss a synthesis of these themes below in the last section of our findings, where we provide an overview of the results of studies included in the sample. 


\section{How was Servant Leadership Examined (i.e., the Methodology)?}

All of the 27 quantitative studies used surveys as the data collection method. The two most popular measures of servant leadership theory used by these empirical studies were Laub's (1999) OLA instrument - used by six studies (Herman, 2010; Black, 2010; Cerit, 2010; Cerit, 2009; Irving and Longbotham, 2007; Joseph and Winston, 2005 ) and the Servant Leadership Scale developed by Ehrhart (2004) - used by six studies (Ehrhart, 2004; Jaramillo et al., 2009a, 2009b; Mayer et al., 2008; Neubert et al., 2008; Walumbwa et al., 2010). Instruments that were utilized by two studies included: Barbuto and Wheeler's (2006) instrument (Jenkins and Steward, 2010; Garber et al., 2009); Liden et al.'s. (2008) instrument (Hu and Liden, 2011; Schaubroeck et al., 2011); and Sendjaya et al.'s. (2008) survey (Pekerti and Sendjaya, 2010; Sendjaya and Perketi, 2010). Taylor et al. (2007) used Page and Wong's (1998) self-assessment measure. Washington et al. (2006) used Dennis and Winston's (2003) instrument, which was an adopted version of Page and Wong's (2000) instrument. Rieke, Hammermeister, and Chase (2008) used Hammermeister, Burton, Pickering, Westro, Baldwin, and Chase's (2008) instrument, which was also an adopted version of Page and Wong's instrument. Babakus, Yavas, and Ashill (2011) and Hale and Fields (2007) used lesser known scales, those of Lytle, Hom, and Mokwa (1998) and Dennis (2004) respectively. One study tapped a survey designed by the U.S. Office of Personal Management (OPM). Four studies used surveys developed specifically for the research: Fridell, Belcher, and Messner (2009), Reinke (2004), and McCuddy and Cavin (2008, 2009). In summary, out of 27 survey studies, there were 14 different measures used. It is important to note that the majority of authors combined multiple measurement scales to construct their surveys. In addition, the majority of these measures explored servant leadership theory at 
the unit level of analysis (i.e., group or team performance) while only a few examined it at the individual level of analysis (i.e., individual performance).

Similarly, the 11 qualitative studies used a variety of servant leadership frameworks to inform their analyses, while three studies did not provide any information on frameworks. Four of the qualitative studies used Spear's (1998) 10 characteristics to inform their analyses (Crippen, 2004; Crippen and Wallin, 2008a, 2008b; Strum, 2009). Two studies used Patterson (2003) and Winsten's (2003) models - Dingman and Stone (2007) and Winston (2004). Han et al. (2010) used multiple dimensions and definitions of servant leadership in Western literature including but not limited to: Barbuto and Wheeler (2006); Liden et al. (2008); Ehrhart (2004); and Sendjaya et al. (2008). The multiple quantitative and qualitative measures used by the studies in our sample reinforce our findings for research question one, where it was found that authors have defined servant leadership in various ways. Similarly, as this review demonstrates, there is still not an agreed upon measurement strategy for servant leadership theory.

\section{What were the Results of the Examination?}

Our sample of empirical studies illustrates that servant leadership is a tenable theory. It is viable and valuable on an individual and an organization level, which can lead to increased overall effectiveness of individuals and teams. In Table 3, a synthesis of the conclusions from our sample of articles is divided by theme, with a rating of the evidence to support each individual conclusion. We discuss the results of these empirical studies by theme below.

Cross-cultural applicability. The cross-cultural studies (Hamilton and Bean, 2005 U.S. and UK; Hale and Fields, 2007 - U.S. and Ghana; Han et al., 2010 - U.S. and China; Pekerti and Sendjaya, 2010 - Indonesia and Australia; Schaubroeck, et al. (2011) - U.S. and China) all indicate servant leadership's acceptability across a variety of cultures. However, these 
studies also show that the different attributes perceived to make up servant leadership are not weighted equally across cultures. For example: Hale and Fields (2007) found that vision had a significantly stronger relationship with leader effectiveness for Ghanaians in comparison to North Americans; Han, Kakabadse, and Kakabadse (2009) found "being dutiful" to be an extended form of servant leadership in China; Hamilton and Bean (2010) discovered that introducing servant leadership within a Christian context was perceived as obtrusive in the United Kingdom; and Perkerti and Sedjaya (2010) found that Australian leaders exhibited more behaviors with authentic self (leadership flows out of who we are as opposed to what we do), while Indonesian leaders exhibited more behaviors with responsible morality (reflective moral reasoning employed to assess whether or not the process and outcomes of one's leadership are ethical) and transforming influence (articulation and implementation of a shared vision which provides inspiration, meaning to one's work, and creates a positive work environment). In contrast to these findings, Schaubroeck, et al. (2011) found no significant differences in perceptions of servant leadership between Hong Kong and the U.S. These cross-cultural studies, along with studies conducted in different countries, imply that servant leadership might be practiced across a variety of cultures, but culture-specific perceptions of servant leadership exist based on socialization and national context.

Servant leader attributes. Seven studies explored the conceptual definitions of servant leadership, and found Spear's (1998), Patterson's (2003), and Winston's (2003) attributes to be representative of servant leadership in different contexts. Five studies (Boroski and Greif, 2009; Crippen, 2004; Crippen and Wallin, 2008a, 2008b; Sturm, 2009) within three different contexts (schools, community, and nursing) supported Spear's 10 characteristics (see Table 3). Two studies (Winston, 2004; Dingman and Stone, 2007) provided support for Patterson's (2003) 
leader-to-follower and Winston's (2003) follower-to-leader models of servant leadership.

Patterson's model of leader-follower interaction starts with the leaders' agapaó (love for others)

which she conceptualizes as a collection of the following seven values: being teachable; showing concern for others; demonstrating discipline; seeking the greatest good for the organization; showing mercy in actions and beliefs with all people; meeting the needs of followers and the organization; and creating a place where peace grows within the organization. These seven values are based upon the biblical concept of the seven beatitudes from Matthew 5 (Patterson, 2003; Winston, 2003, 2004). Instead of focusing on leader-follower interaction as Patterson's model does, Winston's model focuses on the follower-to-leader interactions. Winston's followerto-leader model starts with the followers' agapaó and then shows how the followers are servant leaders themselves by utilizing the same variables as Patterson's model. As stated above, studies confirm the applicability of the variables in both of these models: trust, empowerment, vision, altruism, intrinsic motivation, commitment, and service (Winston, 2004; Dingman and Stone, 2007). Thus, the attributes identified by Spears, Patterson, and Winston were represented within the measurement instruments discussed above.

Team level effectiveness. Sixteen empirical studies explored servant leadership theory at a unit level. Overall, these studies found that a servant-led organization enhances leader trust and organizational trust, organizational citizenship behavior, procedural justice, team and leader effectiveness, and the collaboration between team members. Several studies found that a servantled environment provided affirmation of justice and fair treatment, which is positively associated with procedural justice, or the perception of how a work group as a whole is treated (Ehrhart, 2004; Walumbwa et al., 2010; Chung et al., 2010). Procedural justice fosters trust in the servant leader and in the servant-led organization (Joseph and Winston, 2005; Reinke, 2004; Senjaya and 
Pekerti, 2010; Washington et al., 2006). This creates an open and trusting environment, which can enhance collaboration among team members (Garber et al., 2009; Sturm, 2009; Irving and Longbotham, 2007). Collaboration in a servant-led organization creates a helping culture (i.e., a spirit of willingness), which increases team members' organizational citizenship behavior, defined as pro-social and altruistic behaviors that have been shown to improve organizational performance (Ebener and O'Connell, 2010; Hu and Liden, 2011; Ehrhart; Walumbwa et al., 2010). Servant leadership also improves overall team effectiveness (Taylor et al., 2007; Mayer et al., 2008; McCuddy and Cavin, 2008) and can enhance leaders' effectiveness (Irving \& Longbotham, 2007; Schaubroeck et al., 2011; Hu and Liden, 2011). In summary, servant leadership creates a trusting, fair, collaborative, and helping culture that can result in greater individual and organizational effectiveness.

Followers' well-being. Findings from 15 empirical studies illustrate that servant leadership enhances followers' well-being. These studies showed conceptually and empirically how servant leadership influences followers' well-being by creating a positive work climate (Neubert et al., 2008; Black, 2010; Jaramillo et al., 2009a), which is related to greater organizational commitment (Cerit, 2010; Hamilton and Bean, 2005; Hale and Fields, 2007; Han et al., 2010; Pekerti and Sendjaya, 2010). Greater commitment to the organization increases employee job satisfaction (Cerit, 2009; Jenkins and Stewart, 2010; Mayer et al., 2008; Chung, et al., 2010) and consequently decreases employee turnover (Jaramillo et al., 2009b; Babakus et al., 2011). Servant leaders create these positive outcomes by developing trust while nurturing followers, which encourages the creativity, helping behaviors, and well-being of followers (Jaramillo et al., 2009a; Babakus et al., 2011; Rieke et al., 2008). Overall, these studies support the notion that servant leadership can improve followers' well-being. 
Spirituality. One study (Herman, 2010) found a positive connection between workplace spirituality and servant leadership, while six studies explored servant leadership within religious intuitions. In addition, many scholars described servant leadership using the teachings of Jesus Christ as a reference (Ebener and O'Connell; Hamilton and Bean, 2005; Winsten, 2004). Although there appears to be a relationship between spirituality and servant leadership, there was insufficient evidence to draw conclusions for this review.

Demographics. Three studies (Fridell et al., 2009; McCuddy and Cavin, 2009; Taylor et al., 2007) attempted to identify demographic characteristics conducive to practicing servant leadership. However, these studies lacked methodological quality sufficient to support any conclusions. In addition, many of the findings of these studies contradicted each other as well as other studies within our sample. For example, one study found significant differences between men and women's servant leadership style usage - female leaders were more likely to practice daily reflection and consensus building, foster self worth, and engage in healing relationships (Fridell et al., 2009), while another study found no difference (McCuddy and Cavin, 2009). Also, one study found that socio-economic factors were positively related to servant behaviors (McCuddy and Cavin, 2009), while another study found that no demographic variables were significantly related to servant leadership (Taylor et al., 2007) Therefore, it remains to be discovered if there are in fact demographic characteristics that are related to servant leadership.

Implementation of servant leadership. Three studies examined servant leadership in various organizational processes (Hamilton and Bean, 2005 - leadership development; SavageAustin \& Honeycutt, 2011 - organizational change; Dingman and Stone, 2007 - succession planning). Nevertheless, these studies were not supported by other empirical studies nor was their methodological quality sufficient to provide any conclusions. 


\section{LIMITATIONS}

Although this SLR was conducted in a disciplined manner, potential limitations must be acknowledged. We limited the search process to indexed journals available through the authors' university library system that were peer reviewed published articles written in the English language. Thus, this review did not include non-indexed journals or dissertations because they are not peer-reviewed, or peer-reviewed servant leadership articles published in a language other than English. Given the apparent universal interest in servant leadership, as identified in our review, perhaps there are more empirical studies being published in other languages that would complement or contradict some of the conclusions drawn from this review. The methodology and findings of the studies included in the review were assessed by two independent reviewers aided by a critical assessment tool, which was utilized to make the evaluation phase more accurate. However, our attempt to integrate results conducted with qualitative as well as quantitative data analysis may have limited the ability to sufficiently explore all methodological considerations when fusing the findings of both types of empirical studies into a coherent text. In order to guide future scholars in conducting SLRs, more work is needed on how to assess the quality of qualitative and quantitative research in the field of management. Given SLRs origins are in the medical field, which conduct controlled trial studies, there are few critical appraisal tools that are applicable to the research methods used in other disciplines, such as qualitative inquiry and cross-sectional studies.

\section{CONCLUSION}

This SLR demonstrates servant leadership theory is applicable in a variety of cultures, contexts, and organizational settings. Even though Greenleaf first coined the philosophy in the 1970s, it has taken until 2004 for servant leadership to be explored in an empirical manner. This 
SLR did not place any limitation on the publication year of peer-reviewed journal articles; however, no empirical studies were found across all the databases searched before 2004. To date, the majority of research in servant leadership is either attempting to conceptually define and model the theory or develop measurement tools to empirical test it. Thus, the greater part of research on servant leadership is addressing one of the major criticisms of the theoretical construct, which is the difficulty of operationalizing its concepts and principles (Brumback, 1999; Wong and Davey, 2007). Quay is not alone in his sentiments on Greenleaf's works: "For all his good advice and many practical ideas, he is a Don Quixote trying to convince managers to pursue good and eschew evil” (1997: 83). By Greenleaf’s own admission, his ideas are unorthodox, yet the value of this review illustrates that servant leadership works and is a tenable theory.

The first question of this review sought to discover how servant leadership is being defined. Although our findings indicated the majority of authors use Greenleaf (1970, 1972, 1977), Spears (1998), and Laub (1999) to help define servant leadership, there still does not exist an accepted consensus over its definition. This lack of consensus creates confusion (Van Dierendonck, 2011) amongst researchers, as they create their own variations of definitions and theoretical models. Perhaps one day there will be a generally accepted theory of servant leadership, but the empirical cross-cultural studies in this review highlight that while servant leadership has been researched in a variety of cultures, it has different meanings based on socialization and national context. In addition, Greenleaf (1977) argued that servant leadership is an inward life-long journey, implying that the meaning of servant leadership could change throughout one's life time. Therefore, this review does not conclude with a model or another definition of servant leadership; however, it does provide an overview of multiple definitions of 
servant leadership currently being used in empirical studies in order to further our conceptual understanding.

Second, this review explored the contexts in which servant leadership is being empirically investigated. Our review illustrates the diversity of cultures, organizational settings, and research foci in which servant leadership is being explored. There seems to be pronounced interest in investigating servant leadership in the U.S. and throughout the Asia Pacific region; however, there is a paucity of studies being conducted in other parts of the world. Currently, the majority of studies are exploring servant leadership in an educational setting (44\% of our sample). Organizational settings that have received less attention from researchers include medical institutions, public organizations, non-profit organizations, and community-level organizations. Research on servant leadership is concentrated in the fields of leadership, education, business and psychology; whereas, there is only a small number of studies in the fields of nursing, management, personal selling and sales, ethics, parks and recreation administration, services marketing, and sports. The research themes being explored the least are: spirituality, demographics, and implementation of servant leadership. Thus, this review helps researchers identify areas and contexts which are relatively unexplored in relation to servant leadership and thus ripe for further investigation.

Third, this review examined the tools that can be used to measure the existence and outcomes of servant leadership. The multiple quantitative and qualitative measures used by the studies point to the fact that there is currently not an agreed upon measurement instrument of the theoretical construct. This review can point researchers towards the current measurement tools available, how they are being used, and in what contexts they are being applied. Last, this review synthesized the findings of these empirical studies (see Table 3). Seven research themes 
emerged: cross-cultural applicability, servant leadership attributes, team level effectiveness, followers' well-being, spirituality, demographics, and implementation of servant leadership. This synthesis can help researchers identify the current findings in the extant literature and to discover research foci that remain relatively underexplored.

Several intriguing directions for future research emerged from our SLR. First, this SLR only identified 39 empirical studies that explored servant leadership theory in organizational settings, highlighting the need for researchers to empirically investigate the construct of servant leadership in a variety of organizational contexts. In the burgeoning field of entrepreneurship, researchers could explore how to build a servant-led organization, or in the field of organizational change, studies could explore how to implement servant leadership in an established organization or during a merger or acquisition. Second, there is a need to investigate the antecedents of servant leadership development, such as personal attributes of the leader, background of the leader, and organizational history and trajectory. Third, researchers can examine other outcomes of servant leadership, such as voluntarily organizational turnover, succession planning, affective organizational commitment, and employee well-being through generative growth. Last, there is a need to develop critical appraisal tools for quantitative and quantitative research used in the field of management to conduct SLRs. Perhaps our integration of several appraisal tools can serve as a template, as we assessed the level of supporting evidence for thematic conclusions drawn from combining the results of multiple studies.

This SLR is the first synthesis of empirical studies exploring servant leadership theory in organizational contexts that utilizes a rigorous methodology to mitigate bias through exhaustive literature searches and by providing an audit trail of the conclusions. This review enhances our understanding of the definition(s) of servant leadership, illustrates the diversity of cultures, 
organizational settings, and research foci in which it is being examined, identifies tools that can be used to measure its existence and outcomes, and shows that servant leadership is a viable leadership theory that helps organizations and the well-being of followers. Our findings synthesize empirical research on servant leadership theory across the multidisciplinary fields of business, medicine, psychology, religion, leisure, education, and economics and law. Scholars exploring servant leadership are using theories from other disciplines to build upon existing theory and to develop theory that is uniquely applicable to their field (e.g., organizational behavior, sport, gender). Thus, this SLR validated servant leadership as a viable and valuable theory, and therefore, illustrates how servant leadership theory can be used to inform future empirical studies. In addition, and importantly, this SLR contributes to advancing the methodology of conducting a SLR in the management context. Here, we showcase how a SRL can provide an effective method for mapping out thematically the current body of research literature that empirically explores servant leadership theory in organizational contexts. However, this type of systematic review with rigorous methodology can be applied to other research streams within management as an aid in holistically synthesizing the state of the field in various topical areas.

As a viable leadership theory, servant leadership can perhaps provide the ethical grounding and leadership framework needed to help address the challenges of the $21^{\text {st }}$ century: technological advancements, economic globalization, increased communications, the Internet, rising terrorism, environmental degradation, war and violence, disease and starvation, threat of global warming, intensifying gap between the poor and rich worldwide, as well as many other unsolved issues. Servant leadership contrasts, traditional leader-first paradigms, which applaud a Darwinism, individualistic, and capitalist approach to life, implicating that only the strong will 
survive. Sadly, this belief system is operating at the heart of most organizations and is the consequence of most of our modern tragedies: Arthur Andersen and Enron, Dennis Kozlowski and Tyco, and Bernard Ebbers and WorldCom (Forbes, 2002). Servant leaders believe "the world does not have to be like this" (Keith, 2008, p. ix) and actively work at changing society for the better. In short, this review shows servant leadership can help address these ethical dilemmas. 


\section{REFERENCES}

Akuchie, N. D: 1993, 'The servants and the superstars: An examination of servant leadership in light of Matthew 20: 20-29', Christian Education Journal, 16 (1), 39-43.

Anderson, J.A: 2009, 'When a servant-leader comes knocking. . . ’, Leadership \& Organization Development Journal, 30(1), 4-15.

Babakus, E., Yavas, U., and Ashill, N. J.: 2011, 'Service worker burnout and turnover intentions: Roles of person-job fit, servant leadership, and customer orientation', Services Marketing Quarterly, 32(1), 17-31.

Banutu-Gomez, M.B., and Banutu-Gomez, S.M.T: 2007, 'Leadership and organizational change in a competitive environment', Business Renaissance Quarterly, 2(2), 69-91.

Barbuto, J.E., and Wheeler, D.W.: 2006, 'Scale development and construct clarification of servant leadership', Group \& Organization Management, 31, 300-326.

Barrow, J.C.: 1977, 'The variables of leadership: A review and conceptual framework', Academy of Management Review, 2, 233-251.

Bass, B.M.: 2000, 'The future of leadership in the learning organization', Journal of Leadership Studies, 7(3), 18-38.

Black, G. L.: 2010, Correlational analysis of servant leadership and school climate', Catholic Education: A Journal of Inquiry \& Practice, 13(4), 437-466.

Block, P.: 1993, Stewardship: Choosing Service over Self Interest. (Berrett-Koehler Publishers, San Francisco, CA).

Bordas, J.: 1995, Power and passion: Finding personal purpose. In L. Spears (Eds.), Reflections of leadership: How Robert K. Greenleaf's theory of servant leadership influenced today's top management thinkers (John Wiley \& 
Sons, Inc, New York, NY). pp. 179-193.

Boroski, E., and Greif, T. B: 2009, 'Servant-leaders in community colleges: Their values, beliefs, and implications', Review of Business Research, 9(4), 113-120.

Bowman, M.A: 1997, Popular approaches to leadership. In P.G. Northhouse (Eds.) Leadership: Theory and Practice (Sage, Thousand Oaks, CA) pp. 239-260..

Brody, D.: 1995, First among equals: A corporate executive's vision and the reemerging philosophy of trustees as servant-leaders. In L. Spears (Eds.), Reflections of leadership: How Robert K. Greenleaf's theory of servant leadership influenced today's top management thinkers (John Wiley \& Sons, Inc., New York) pp. 129-132.

Buchen, I. H.: 1998), 'Servant leadership: A model for future faculty and future institutions', The Journal of Leadership Studies, 5(1), 125-134.

Cerit, Y.: 2009, 'The effects of servant leadership behaviors of school principals on teachers' job satisfaction', Educational Management Administration \& Leadership, 37(5): 600-623.

Cerit, Y.: 2010, 'The effects of servant leadership on teachers' organizational commitment in primary schools in Turkey', International Journal of Leadership in Education, 13(3), 301-317.

Chamberlain, P.:1995, Team-building and servant-leadership. In L. Spears (Eds.), Reflections of leadership: How Robert K. Greenleaf's theory of servant leadership influenced today's top management thinkers (John Wiley \& Sons, Inc, New York) pp. 169-178.

Chung, J. Y., Jung, C. S., Kyle, G. T., and Petrick, J. F.: 2010, 'Servant leadership and procedural justice in the U.S. national park service: The antecedents of job satisfaction', Journal of Park \& Recreation Administration, 28(3), 1-15. 
Cook, D. J., Mulrow, C. D., and Haynes, R. B.: 1997, 'Systematic reviews: Synthesis of best evidence for clinical decisions', Annals of Internal Medicine, 126(5), 376-380.

Covey, S.: 1990, Principle centered leadership (Simon and Schuster, New York)

Crippen, C. L.: 2004, 'Pioneer women in Manitoba: Evidence of servant-leadership'. Journal of Women in Educational Leadership, 2(4), 257-271.

Crippen, C., and Wallin, D.: 2008a, 'First conversations with Manitoba superintendents:

Talking their walk', Alberta Journal of Educational Research, 54(2), 147-160.

Crippen, C., and Wallin, D.: 2008b, 'Manitoba superintendents: Mentoring and leadership'. Educational Management Administration \& Leadership, 36(4), 546-565.

Cyert, R.: 2006, Defining leadership and explicating the process', Nonprofit Management and Leadership, 1(1), 29-38.

De Pree, M.: 1989, Leadership is an art. (Doubleday Business, New York).

Dennis, R.: 2004, Servant leadership theory: Development of the servant leadership assessment instrument. Unpublished PhD Thesis. Regent University, Virginia Beach, Virginia, USA.

Dennis, R. S., and Bocarnea, M. C.: 2005, 'Development of the servant leadership assessment instrument', Leadership and Organization Development Journal 26(8), 600-15.

Dennis, R.S., and Winston, B.: 2003, 'A factor analysis of Page and Wong's servant leadership assessment instrument', Leadership \& Organization Development Journal, $24(8), 455-459$.

DiMaggio, P.: 1995, Comments on "What Theory is Not.", Administrative Science Quarterly, 40, 391-397. 
Dingman, W. W., and Stone, A. G.: 2007, 'Servant leadership's role in the succession planning process: A case study', International Journal of Leadership Studies, 2(2), 98-113.

Ebener, D. R., and O'Connell, D. J.: 2010, 'How might servant leadership work?', Nonprofit Management and Leadership, 20(3), 315-335.

Ehrhart, M. G.: 2004, 'Leadership and procedural justice climate as antecedents of unit level organizational citizenship behavior', Personnel Psychology, 57(1), 61-94.

Farling, M.L., Stone, A.G., and Winston, B.E.: 1999, 'Servant leadership: Setting the stage for empirical research', Journal of Leadership Studies, 6, 49-62.

Forbes.: 2010, The corporate scandal sheet. Retrieved November $25^{\text {th }}$ from http://www.forbes.com/2002/07/25/accountingtracker.html

Frick, D. M.: 1995, Pyramids, circles, and gardens: Stories of implementing servant leadership. In L. Spears (Eds.), Reflections of leadership: How Robert K. Greenleaf's theory of servant-leadership influenced today's top management thinkers (John Wiley \& Sons, Inc, New York) pp. 241-256.

Frick, D.M.: 2004, Robert K. Greenleaf: A life of servant leadership. (Berrett-Koehler, San Francisco, CA)

Fridell, M., Belcher, R. N., and Messner, P. E.: 2009, 'Discriminate analysis gender public school principal servant leadership differences’, Leadership \& Organization Development Journal, 30(8), 722-736.

Garber, J. S., Madigan, E. A., Click, E. R., and Fitzpatrick, J. J.: 2009, 'Attitudes towards collaboration and servant leadership among nurses, physicians and residents', Journal of Interprofessional Care, 23(4), 331-340. 
Garrard, J.: 1999, Health sciences literature review made easy: The matrix method (Jones and Barlett Publishers, Sudbury, MA).

Gaston, H.G.: 1987, ‘A model for leadership: Servant stewardship ministry', Southwestern Journal of Theology, 37(2), 35-43.

Graham, J.: 1991, 'Servant-leadership in organizations: Inspirational and moral', Leadership Quarterly, 2(2), 105-119.

Greenleaf Center, Inc.: 2011. Retrieved July, 10, 2011 from http://www.greenleaf.org/.

Greenleaf, R.K.: 1970. The servant as leader (The Robert K. Greenleaf Center, Indianapolis).

Greenleaf, R. K.: 1972. The institution as servant (The Robert K. Greenleaf Center, Indianapolis).

Greenleaf, R. K.: 1972. Trustees as servants (The Robert K. Greenleaf Center, Indianapolis). Greenleaf, R. K.: 1977. Servant leadership: A journey into the nature of legitimate power and greatness (Paulist Press, New York).

Hale, J. R., and Fields, D. L.: 2007, 'Exploring servant leadership across cultures: A study of followers in Ghana and the USA', Leadership, 3(4), 397-417.

Hamilton, F., and Bean, C. J.: 2005, 'The importance of context, beliefs and values in leadership development', Business Ethics: A European Review, 14(4), 336-347.

Hammermeister, J., Burton, D., Pickering, M. A., Westro, K., Baldwin, N., and Chase, M.: 2008, 'Servant leadership in sport: A Philosophy whose time has arrived', International Journal of Servant Leadership, 4, 185-215.

Han, Y., Kakabadse, N. K., and Kakabadse, A.: 2010, 'Servant leadership in the People's Republic of China: A case study of the public sector', Journal of Management Development, 29(3), 265-281. 
Herman, R.: 2010, 'The promise of servant leadership for workplace spirituality', International Journal of Business Research, 10(6), 83-102.

Hesse, H.: 1956, The Journey of the East (Noonday Press, New York).

Hu, J., and Liden, R. C.: 2011, 'Antecedents of team potency and team effectiveness: An examination of goal and process clarity and servant leadership', Journal of Applied Psychology, doi:10.1037/a0022465, 1-12.

Institute for Public Health Sciences: 2002, 11 questions to help you make sense of descriptive/cross-sectional studies. New York, NY: Yeshiva University.

Irving, J. A., and Longbotham, G. J.: 2007, 'Team effectiveness and six essential servant leadership themes: A regression model based on items in the organizational leadership assessment', International Journal of Leadership Studies, 2(2), 98-113.

Jaramillo, F., Grisaffe, D. B., Chonko, L. B., and Roberts, J. A.: 2009a, 'Examining the impact of servant leadership on sales force performance', Journal of Personal Selling \& Sales Management, 29(3), 257-275.

Jaramillo, F., Grisaffe, D. B., Chonko, L. B., and Roberts, J. A.: 2009b, 'Examining the impact of servant leadership on salesperson's turnover intention', Journal of Personal Selling \& Sales Management, 29(4), 351-365.

Jenkins, M., and Stewart, A. C.: 2010, 'The importance of a servant leader orientation', Health Care Management Review, 35(1), 46-54.

Joseph, E. E., and Winston, B. E.: 2005, 'A correlation of servant leadership, leader trust, and organizational trust', Leadership \& Organization Development Journal, 26(1), 6-22. 
Kelley, M.: 1995, The new leadership. In L. Spears (Eds.), Reflections of leadership: How Robert K. Greenleaf's theory of servant-leadership influenced today's top management thinkers (John Wiley \& Sons, Inc., New York). pp. 194-197.

Kiechel, III, W.: 1995, The leader as servant. In L. Spears (Eds.), Reflections of leadership: How Robert K. Greenleaf's theory of servant-leadership influenced today's top management thinkers (John Wiley \& Sons, Inc., New York) pp. 121-125.

Klassen, T. P., Jahad, A. R., and Moher, D.: 1998, 'Guides for reading and interpreting systematic reviews', Archives of Pediatric \& Adolescent Medicine, 157 (7), 700-704.

Kotter, J.P.: 2001, 'What leaders really do?', Harvard Business Review, December, 3-12.

Kuhnert, K. W., and Lewis, P.: 1987, 'Transactional and transformational leadership: A constructive/developmental analysis', Academy of Management Review, 12(4), 648-657.

Lanctot, J.D., and Irving, J.A.: 2010, 'Character and leadership: Situating servant leadership in a proposed virtues framework', International Journal of Leadership Studies, 6(1), 28-50.

Laub, J.: 1999, 'Assessing the servant organization: Development of the Servant Organizational Leadership (SOLA) instrument'. Dissertation Abstracts International, 60(2): 308. (UMI No.9921922)

Lee, C., and Zemke, R.: 1995, The search for spirit in the workplace. In L. Spears (Eds.), Reflections of leadership: How Robert K. Greenleaf's theory of servant leadership influenced today's top management thinkers (John Wiley \& Sons, Inc., New York) pp. 99-112.

Letts, L., Wilkins, S., Law, M., Stewart, D., Bosch, J., and Westmorland, M.: 2007, Critical review form: Qualitative studies (version 2.0). Retrieved from http://www.sph.nhs.uk/sphfiles/caspappraisaltools/Qualitative\%20Appraisal\%20Tool.pdf 
Liden, R. C., Wayne, S.J, Zhao, H., and Henderson, D.: 2008, 'Servant leadership:

Development of a multidimensional measure and multi-level assessment', Leadership Quarterly, 19, 161-177.

Lloyd, B.: 1996, ‘A new approach to leadership', Leadership \& Organizational Development Journal, 17(7), 29-32.

Lopez, I.O.: 1995, Becoming a servant-leader: The personal development path. In L. Spears (Eds.), Reflections of leadership: How Robert K. Greenleaf's theory of servant leadership influenced today's top management thinkers (John Wiley \& Sons, Inc., New York) pp. 179-193.

Lytle, R. S., Hom, P. W., and Mokwa, M. P.: 1998, 'SERV_OR: A managerial measure of organizational service-orientation', Journal of Retailing, 74, 455-489.

Mayer, D. M., Bardes, M., and Piccolo, R. F.: 2008, 'Do servant-leaders help satisfy follower needs? An organizational justice perspective', European Journal of Work and Organizational Psychology, 17(2), 180-197.

McCollum, J.: 1995, Chaos, complexity, and servant-leadership. In L. Spears (Eds.), Reflections of leadership: How Robert K. Greenleaf's theory of servant leadership influenced today's top management thinkers (John Wiley \& Sons, Inc., New York) pp. 241-256.

McCuddy, M. K., and Cavin, M. C.: 2008, 'Fundamental moral orientations, servant leadership, and leadership effectiveness: An empirical test', Review of Business Research, 8(4), 107-117.

McCuddy, M. K., and Cavin, M. C.: 2009, 'The demographic context of servant leadership', Journal of the Academy of Business \& Economics, 9(2), 129-139. 
McGee-Cooper, A., and Trammell, D.: 1995, Servant leadership: Is there really time for it? In

L. Spears (Eds.), Reflections of leadership: How Robert K. Greenleaf's theory of servant leadership influenced today's top management thinkers (John Wiley \& Sons, Inc., New York) pp. 113-120.

Neubert, M. J., Kacmar, K. M., Carlson, D. S., Chonko, L. B., and Roberts, J. A.: 2008, 'Regulatory focus as a mediator of the influence of initiating structure and servant leadership on employee behavior', Journal of Applied Psychology, 93(6), 1220-1233.

Northouse, P.G.: 1997, Leadership: Theory and practice (Sage, Thousand Oaks, CA).

OLA Group (Organizational Leadership Assessment Group).: 2011, Retrieved September 4, 2011 from http://www.olagroup.com/

Page, D., and Wong, T. P.: 1998, 'A philosophy conceptual framework for measuring servant leadership', Unpublished manuscript (Langley, Canada: Trinity Western University).

Page, D., and Wong, T.P.: 2000, A philosophy conceptual framework for measuring servant leadership. In Adjibolosoo, S. (Ed.), The Human factor in shaping the course of history and development (University Press of America, Lanham, MD).

Patterson, K.: 2003, 'Servant leadership: A theoretical model', Dissertation Abstracts International, 64(2), 570. (UMI No. 3082719).

Pekerti, A. A., and Sendjaya, S.: 2010, 'Exploring servant leadership across cultures: Comparative study in Australia and Indonesia', The International Journal of Human Resource Management, 21(5), 754-780.

Plsek, P., and Wilson, T.: 2001, 'Complexity, leadership, and management in healthcare organizations', British Medical Journal (BMJ), 323, 746-749. 
Prosser, S.: 2010, Servant Leadership: More Philosophy, Less Theory (The Greenleaf Center for Servant Leadership, Westfield, IN)

Rasmussen, T.: 1995, Creating a culture of servant leadership: A real life story. In L. Spears (Eds.), Reflections of leadership: How Robert K. Greenleaf's theory of servant leadership influenced today's top management thinkers (John Wiley \& Sons, Inc., New York) pp. 282-307.

Reinke, S. J.: 2004, 'Service before self: Towards a theory of servant-leadership', Global Virtue Ethics Review, 5, 30-57.

Rieke, M., Hammermeister, J., and Chase, M.: 2008, 'Servant leadership in sport: A new paradigm for effective coach behavior', International Journal of Sports Science \& Coaching, 3(2), 227-239.

Rieser, C.: 1995, Claiming servant-leadership as your heritage. In L. Spears (Eds.), Reflections of leadership: How Robert K. Greenleaf's theory of servant leadership influenced today's top management thinkers (John Wiley \& Sons, Inc., New York) pp. 49-60.

Russell, R.: 2001, 'The role of values in servant leadership', Leadership \& Organization Development Journal, 22(2), 76-83.

Russell, R., and Stone, A.G.: 2002, 'A review of servant leadership attributes: Developing a practical model', Leadership \& Organizational Development Journal, 23(3): 145-157.

Savage-Austin, A., and Honeycutt, A., 2011, 'Servant leadership: A phenomenological study of practices, experiences, organizational effectiveness, and barriers', Journal of Business \& Economics Research, 9(1), 49-54. 
Schaubroeck, J., Lam, S. S. K., and Peng, A. C.: 2011, 'Cognition-based and affect-based trust as mediators of leader behavior influences on team performance', Journal of Applied Psychology, 96(4): 863-871.

Schneider, B.: 1987, 'The people make the place', Personnel Psychology, 40, 437-453.

Sendjaya, S., and Pekerti, A.: 2010, 'Servant leadership as antecedent of trust in organizations', Leadership \& Organization Development Journal, 31(7), 643-663.

Sendjaya, S., and Sarros, J.: 2002, 'Servant leadership: Its origin, development, and application in organizations', Journal of Leadership and Organizational Studies, 9(2), 57-64.

Sendjaya, S., Sarros, J., and Santora, J.: 2008, 'Defining and measuring servant leadership behavior in organizations', Journal of Management Studies, 45(2), 402-424.

Senge, P. M.: 1995, Robert's Greenleaf's legacy: A new foundation for twenty-first century institutions. In L. Spears (Eds.), Reflections of leadership: How Robert K. Greenleaf's theory of servant-leadership influenced today's top management thinkers (John Wiley \& Sons, Inc., New York) pp. 217-240.

Senge, P.: 1990, The Fifth discipline: The art and styles of the learning organization (Doubleday Business, New York).

Shannon, R., 1999, 'Sport marketing: An examination of academic marketing publication’, Journal of Services Marketing, 13(6), 517-534.

Smith, W.: 1995, Servant-leadership: A pathway to the emerging territory: In L. Spears (Eds.), Reflections of leadership: How Robert K. Greenleaf's theory of servant leadership influenced today's top management thinkers (John Wiley \& Sons, Inc., New York) pp. 198-213. 
Snodgrass, K.R.: 1993, Your slaves—on account of Jesus' servant leadership in the New Testament. In J.R. Hawkinson, \& R.K. Johnston (Eds.) Servant leadership (Covenant Publications, Chicago) pp. 7-19.

Spears Center.: 2011, Retrieved September 5, 2011 from http://www.spearscenter.org/. Spears, L.: 1995, Introduction: Servant-leadership and the Greenleaf legacy. In L. Spears (Eds.), Reflections of leadership: How Robert K. Greenleaf's theory of servant leadership influenced today's top management thinkers (John Wiley \& Sons, Inc., New York) pp. 116.

Spears, L.: 1996, 'Reflections on Robert K. Greenleaf and servant-leadership', Leadership \& Organization Development, 17(7), 33-35.

Spears, L.: 1998, Insights on leadership: Service, stewardship, spirit, and servant leadership (John Wiley and Sons, Inc., New York).

Spears, L. C.: 2004, 'Practicing servant-leadership', Leader to Leader, 34, 7-11.

Spears, L. C.: 2005, On character and servant-leadership: Ten characteristics of effective, caring leaders. Greenleaf Center for Servant-Leadership. Retrieved July 12, 2011 from: http://www.greenleaf.org/leadership/read-about-it/ articles/On-Character-and-Servant-Leadership-Ten-Characteristics.htm

Stoltz, P., Udén, G., and Willman, Ania.: 2004, ‘Support for family careers who care for an elderly person at home - A systematic literature review', Scand J Caring Sci, 18, 111118.

Sturm, B. A.: 2009, Principles of servant-leadership in community health nursing: Management issues and behaviors discovered in ethnographic research', Home Health Care Management \& Practice, 21(2), 82-89. 
Tatum. J. G.: 1995, Meditations on servant-leadership. In L. Spears (Eds.), Reflections of leadership: How Robert K. Greenleaf's theory of servant-leadership influenced today's top management thinkers (John Wiley \& Sons, Inc., New York) pp. 308-312.

Taylor, T., Martin, B. N., Hutchinson, S., and Jinks, M.: 2007, 'Examination of leadership practices of principals identified as servant leaders', International Journal of Leadership in Education, 10(4), 401-419.

Thorpe, R., Holt, R., Pittaway, L., and Macpherson, A.: 2006, 'Knowledge within small and medium sized firms: A systematic review of the evidence', International Journal of Management Reviews, 7(4), 257-281.

Tranfield, D., Denyer, D., and Smart, P.: 2003, 'Towards a methodology for developing evidence-informed management knowledge by means of systematic review', British Journal of Management, 14, 207-222.

Van Dierendonck, D.: 2011, 'Servant leadership: A review and syntheses', Journal of Management, 27(4), 1228-1261.

Van Dierendonck, D., and Nuijte, K.: 2011, 'The Servant-Leadership Survey (SLS):

Development and validation of a multidimensional measure', Journal of Business in Psychology, doi: 10.1007/s10869-010-9194-1.

Van Dierendonck, D., and Patterson, K.: 2011, Servant leadership, recent development in theory and research. Presented at Greenleaf Center's annual international conference, Dallas, TX.

Vanourek, R. A.: 1995: Servant-leadership and the future. In L. Spears (Eds.), Reflections of leadership: How Robert K. Greenleaf's theory of servant leadership influenced today's top management thinkers (John Wiley \& Sons, Inc., New York) pp. 298-307. 
Walumbwa, F. O., Hartnell, C. A., and Oke, A.: 2010, 'Servant leadership, procedural justice climate, service climate, employee attitudes, and organizational citizenship behavior: A cross-level investigation', Journal of Applied Psychology, 95(3), 517-529.

Washington, R. R., Sutton, C. D., and Feild, H. S.: 2006, 'Individual differences in servant leadership: The roles of values and personality', Leadership \& Organization Development Journal, 27(8), 700-716.

Weed, M.: 2005, “"Meta interpretation”: A method for interpretive synthesis of qualitative research', Forum: Qualitative Social Research (FQS), 6(1). 1-21.

Wheatley, M.: 2005, Finding our way: Leadership in an uncertain times (Berrett-Koehler Publishers, San Francisco). .

Whetstone, J.: 2002, 'Personalism and moral leadership: the servant leader with a transforming vision', Leadership \& Organizational Development Journal, 25(3/4), 349-59.

Winston, B. E.: 2003, Extending Patterson's servant leadership model: Explaining how leaders and followers interact in a circular model. Servant Leadership Research Roundtable, Virginia Beach, VA.

Winston, B. E.: 2004, 'Servant leadership at Heritage Bible College: A single-case study', Leadership \& Organization Development Journal, 25(7), 600-617.

Wong, P. T., and Davey, D.: 2007: Best practices of servant leadership. Servant Leadership Research Roundtable. Virginia Beach, VA: Regent University.

Wong, P.T., and Page, D.: 2003, Servant leadership: An opponent-process model and the revised servant leadership profile. Servant Leadership Research Roundtable, Virginia Beach, VA. 
TABLE 1

DATABASE AND JOURNALS INCLUDED IN SYSTEMATIC LITERATURE REVIEW

\begin{tabular}{|c|c|c|}
\hline Database & Journal & Count \\
\hline Eric & Alberta Journal of Educational Research & 1 \\
\hline PsycInfo & Business Ethics: A European Review & 1 \\
\hline Eric & Catholic Education: A Journal of Inquiry \& Practice & 1 \\
\hline Eric & Educational Management Administration \& Leadership & 2 \\
\hline PsycInfo & $\begin{array}{l}\text { European Journal of Work and Organizational } \\
\qquad \text { Psychology }\end{array}$ & 1 \\
\hline Scopus & Global Virtue Ethics Review & 1 \\
\hline CINAHL & Health Care Management Review & 1 \\
\hline PsycInfo & Home Health Care Management \& Practice & 1 \\
\hline $\begin{array}{l}\text { Business Source } \\
\text { Complete }\end{array}$ & International Journal of Business Research & 1 \\
\hline Eric & International Journal of Leadership in Education & 2 \\
\hline Scopus & International Journal of Leadership Studies & 2 \\
\hline PsycInfo & International Journal of Sports Science \& Coaching & 1 \\
\hline PsycInfo & Journal of Applied Psychology & 3 \\
\hline $\begin{array}{l}\text { Business Source } \\
\text { Complete }\end{array}$ & Journal of Business \& Economics Research & 1 \\
\hline $\begin{array}{l}\text { Academic Search } \\
\text { Complete }\end{array}$ & Journal of Interprofessional Care & 1 \\
\hline PsycInfo & Journal of Management Development & 1 \\
\hline $\begin{array}{l}\text { Academic Search } \\
\text { Complete }\end{array}$ & Journal of Park \& Recreation Administration & 1 \\
\hline PsycInfo & Journal of Personal Selling \& Sales Management & 2 \\
\hline $\begin{array}{l}\text { Business Source } \\
\text { Complete }\end{array}$ & Journal of the Academy of Business \& Economics & 1 \\
\hline Eric & Journal of Women in Educational Leadership & 1 \\
\hline PsycInfo & Leadership & 1 \\
\hline PsycInfo & Leadership \& Organization Development Journal & 6 \\
\hline PsycInfo & Nonprofit Management and Leadership & 1 \\
\hline PsycInfo & Personnel Psychology & 1 \\
\hline $\begin{array}{l}\text { Business Source } \\
\text { Complete }\end{array}$ & Review of Business Research & 2 \\
\hline $\begin{array}{l}\text { Business Source } \\
\text { Complete }\end{array}$ & Services Marketing Quarterly & 1 \\
\hline PsycInfo & $\begin{array}{c}\text { The International Journal of Human Resource } \\
\text { Management }\end{array}$ & 1 \\
\hline
\end{tabular}


TABLE 2

\section{CLASSIFICATION AND QUALITY ASSESSMENT OF STUDIES}

\begin{tabular}{|c|c|c|c|}
\hline & I = High & $\mathrm{II}=$ Medium & III = Low \\
\hline QNT & $\begin{array}{l}\text { Study using quantitative analysis of data. Clearly } \\
\text { focused study, sufficient background provided, well } \\
\text { planned, method appropriate, measures validated, } \\
\text { applicable and adequate number of participants, data } \\
\text { analysis sufficiently rigorous with adequate statistical } \\
\text { methods, findings clearly stated. }\end{array}$ & - & $\begin{array}{l}\text { Not focused study, insufficient background provided, } \\
\text { poorly planned, inappropriate method, invalidated } \\
\text { measures, inapplicable and inadequate number of } \\
\text { participants, data analysis insufficiently rigorous, with } \\
\text { inadequate statistical methods, unclear findings. }\end{array}$ \\
\hline QAL & $\begin{array}{l}\text { Study using qualitative analysis of data. Purpose stated } \\
\text { clearly, relevant background literature reviewed, design } \\
\text { appropriate, identified researcher's theoretical or } \\
\text { philosophical perspective, relevant and well described } \\
\text { selection of participants and context, procedural rigor in } \\
\text { data collection strategies and analysis, evidence of the } \\
\text { four components of trustworthiness (credibility, } \\
\text { transferability, dependability, and confirmability) } \\
\text { results are comprehensive and well described. }\end{array}$ & - & $\begin{array}{l}\text { Vaguely formulated purpose, insufficient background, } \\
\text { few or unsatisfactory descriptions of participants and } \\
\text { context, trustworthiness inadequately addressed, lacks } \\
\text { in description of data collection, data analysis, and } \\
\text { results. }\end{array}$ \\
\hline
\end{tabular}

QNT, quantitative study; QAL, qualitative study; I, high quality; II, medium quality; III, low quality. 
TABLE 3: OVERVIEW OF CONCLUSIONS

\begin{tabular}{|c|c|c|c|}
\hline Result Themes & Conclusion & Evidence & References \\
\hline $\begin{array}{l}\text { Cross-cultural } \\
\text { applicability }\end{array}$ & $\begin{array}{l}\text { SL is accepted and practiced in various cultures; however, } \\
\text { components of SL have different weights }\end{array}$ & Strong evidence in favor of statement (A) & $\begin{array}{l}\text { Cerit, (2009, 2010) (QNT I, QNT I); Hamilton \& Bean (2005) } \\
\text { (QAL III); Hale \& Fields, (2007) (QNT I); Han et al., (2010) } \\
\text { (QAL II); Pekerti \& Sendjaya, (2010) (QNT I) }\end{array}$ \\
\hline \multirow[t]{2}{*}{ SL attributes } & $\begin{array}{l}\text { Spears' (1998) } 10 \text { characteristics are representative of a servant } \\
\text { leader applied in different context }\end{array}$ & Strong evidence in favor of statement (A) & $\begin{array}{l}\text { Boroski \& Greif, (2009) (QAL III); Crippen, (2004) (QAL II); } \\
\text { Crippen \& Wallin, (2008a) (QAL II), (2008b) (QAL II); Sturm, } \\
\text { (2009) (QAL I) }\end{array}$ \\
\hline & Patterson (2003) and Winston (2003) models of SL are supported & Strong evidence in favor of statement (A) & Winston, (2004) (QAL I); Dingman \& Stone (2007) (QAL II) \\
\hline \multirow[t]{6}{*}{$\begin{array}{l}\text { Team level } \\
\text { effectiveness }\end{array}$} & SL leads to increased leader trust and organizational trust & Strong evidence in favor of statement (A) & $\begin{array}{l}\text { Joseph \& Winston, (2005) (QNT I); Reinke, (2004) (QNT II); } \\
\text { Senjaya \& Pekerti, (2010) (QNT I); Washington et al, (2006) } \\
\text { (QNT I) }\end{array}$ \\
\hline & SL fosters organizational citizenship behavior & Strong evidence in favor of statement (A) & $\begin{array}{l}\text { Ebener \& O'Connell, (2010) (QAL I); Hu \& Liden, (2011) (QNT } \\
\text { I); Ehrhart, (2004) (QNT I); Walumbwa et al, (2010) (QNT I) }\end{array}$ \\
\hline & Procedural justice is positively associated with SL & Strong evidence in favor of statement (A) & $\begin{array}{l}\text { Ehrhart, (2004) (QNT I); Walumbwa et al, (2010) (QNT I); } \\
\text { Chung, et al., (2010) (QNT II) }\end{array}$ \\
\hline & SL increases team effectiveness & Strong evidence in favor of statement (A) & $\begin{array}{l}\text { Irving \& Longbotham, (2007) (QNT I); Schaubroeck et al (2011) } \\
\text { (QNT I); Hu \& Liden, (2011) (QNT I) }\end{array}$ \\
\hline & SL is associated with greater leadership effectiveness & Strong evidence in favor of statement (A) & $\begin{array}{l}\text { Taylor et al, (2007) (QNT II); Mayer et al., (2008) (QNT I); } \\
\text { McCuddy \& Cavin, (2008) (QNT III) }\end{array}$ \\
\hline & SL enhances collaboration & Moderate evidence in favor of statement (B) & $\begin{array}{l}\text { Garber et al., (2009) (QNT II); Sturm, (2009) (QAL I); Irving \& } \\
\text { Longbotham, (2007) (QNT I) }\end{array}$ \\
\hline \multirow[t]{6}{*}{$\begin{array}{l}\text { Followers' } \\
\text { well-being }\end{array}$} & SL increases employee job satisfaction & Strong evidence in favor of statement (A) & $\begin{array}{l}\text { Cerit, (2009) (QNT I); Jenkins \& Stewart, (2010) (QNT I); } \\
\text { Mayer et al., (2008) (QNT I); Chung, et al., (2010) (QNT II) }\end{array}$ \\
\hline & SL creates a positive work climate & Strong evidence in favor of statement (A) & $\begin{array}{l}\text { Neubert et al., (2008) (QNT I); Black, (2010) (Mixed Method: } \\
\text { QNT II \& QAL III); Jaramillo et al., (2009a) (QNT I) }\end{array}$ \\
\hline & SL supports employee creativity and helping behaviors & Strong evidence in favor of statement (A) & Jaramillo et al., (2009b) (QNT I); Neubert et al., (2008) (QNT I) \\
\hline & SL improves followers well-being & Strong evidence in favor of statement (A) & Jaramillo et al., (2009b) (QNT I); Rieke et al., (2008) (QNT I) \\
\hline & SL lowers employee turnover & Strong evidence in favor of statement (A) & Jaramillo et al., (2009a) (QNT I); Babakusa et al., (2011) (QNT I) \\
\hline & SL increases commitment & Strong evidence in favor of statement (A) & $\begin{array}{l}\text { Cerit, (2010) (QNT I); Hamilton \& Bean (2005) (QAL III); Hale } \\
\text { \& Fields, (2007) (QNT I); Han et al., (2010) (QAL II); Pekerti \& } \\
\text { Sendjaya, (2010) (QNT I) Jaramillo et al., (2009a) (QNT I); } \\
\text { Jaramillo et al., (2009b) (QNT I) }\end{array}$ \\
\hline Spirituality & SL is associated with workplace spirituality & Insufficient evidence & Herman, (2010) (QNT II) \\
\hline Demographics & $\begin{array}{l}\text { Propensity toward engaging in SL is associated with } \\
\text { demographic variables }\end{array}$ & Insufficient evidence & $\begin{array}{l}\text { Fridell et al., (2009) (QNT II); McCuddy \& Cavin, (2009) (QNT } \\
\text { III); Taylor et al, (2007) (QNT II) }\end{array}$ \\
\hline \multirow[t]{2}{*}{$\begin{array}{l}\text { Implementation } \\
\text { of SL }\end{array}$} & Knowledge and framing of SL can affect adoption & Insufficient evidence & $\begin{array}{l}\text { Hamilton \& Bean (2005) (QAL III); Savage-Austin \& Honeycutt, } \\
\text { (2011) (QAL III) }\end{array}$ \\
\hline & Positive relationship between succession planning and SL & Insufficient evidence & Dingman \& Stone (2007) (QAL II) \\
\hline
\end{tabular}

SL, servant leadership; QNT, quantitative study; QAL, qualitative study; I, high quality; II, medium quality; III, low quality. 
TABLE 4

SPEARS' (1998) 10 CHARACTERISTICS OF A SERVANT LEADER

\begin{tabular}{|c|c|}
\hline Characteristic & Description \\
\hline Listening & $\begin{array}{l}\text { Automatically responding to any problem by receptively } \\
\text { listening to what is said, which allows them to identify } \\
\text { the will of the group and help clarify that will. }\end{array}$ \\
\hline Empathy & $\begin{array}{l}\text { Striving to accept and understand others, never rejecting } \\
\text { them, but sometimes refusing to recognize their } \\
\text { performance as good enough. }\end{array}$ \\
\hline Healing & $\begin{array}{l}\text { Recognizing as human beings they have the opportunity } \\
\text { to make themselves and others 'whole'. }\end{array}$ \\
\hline Awareness & $\begin{array}{l}\text { Strengthened by general awareness and above all self- } \\
\text { awareness, which enables them to view situations } \\
\text { holistically. }\end{array}$ \\
\hline Persuasion & Relying primarily on convincement rather than coercion. \\
\hline Conceptualization & $\begin{array}{l}\text { Seeking to arouse and nurture theirs' and others' abilities } \\
\text { to 'dream great dreams'. }\end{array}$ \\
\hline Foresight & $\begin{array}{l}\text { Intuitively understanding the lessons from the past, the } \\
\text { present realities, and the likely outcome of a decision for } \\
\text { the future. }\end{array}$ \\
\hline Stewardship & Committing first and foremost to serving others needs. \\
\hline $\begin{array}{l}\text { Commitment to the } \\
\text { growth of people }\end{array}$ & $\begin{array}{l}\text { Nurtures the personal, professional, and spiritual growth } \\
\text { of each individual. }\end{array}$ \\
\hline $\begin{array}{l}\text { Building } \\
\text { community }\end{array}$ & $\begin{array}{l}\text { Identifies means of building communities among } \\
\text { individuals working within their institutions, which can } \\
\text { give the healing love essential for health. }\end{array}$ \\
\hline
\end{tabular}

